\title{
Beneficial Effects of Melatonin on Oxidative Damage Observed During Whole Blood Storage
}

\author{
Ilknur S. OZCELIK \\ The Scientific and Technological Research Council of Turkey, Ankara, TURKEY
}

\begin{abstract}
It is well known that oxidative stress rises during the storing period of whole blood and there has been a great interest to improve the quality of stored blood for longer periods. In the present study, we determine the effects of melatonin as an antioxidant on the whole blood indices stored under blood bank conditions. Human blood was collected by venipuncture into citrate-dextrose-phosphate (CDP) bags from healthy volunteers. Immediately after collection, blood was subdivided into two parts and exposed to either melatonin or control saline solutions. Several biochemical parameters were measured on the day of collection and at weekly intervals up to 3 weeks. Mean corpuscular and platelet volumes tended to increase during storing process and with melatonin, these indices remained near to physiologic levels. As expected, acidity, oxidative damage and osmotic fragility increased in stored blood. Interestingly addition of melatonin reduced acidity, oxidative damage by lowering malondialdehyde levels and by increasing superoxide dismutase activity, and osmotic fragility during storage without adversely affecting other biochemical parameters. pH was $6.68 \pm 0.04$ in day 14 of control group while it was $7.00 \pm 0.03$ in melatonin group. Malondialdehyde level was $1.223 \pm 0.05$ in day 21 of control group while it was $0.723 \pm 0.04$ in melatonin group $(p<0.05)$. Superoxide dismutase activity was significantly higher in melatonin group at days 14 and 21 (151.3 \pm 12.2 and $82.8 \pm 9.2)$ compared to saline $(111.8 \pm 6.5$ and $44.8 \pm 3.0)(p<0.05)$. Through these results, we could confirm a central role for oxidative stress in the mechanism of the most evident blood storage lesions and melatonin seems to exhibit beneficial effects on these lesions.
\end{abstract}

Keywords: Whole blood storage, Oxidative stress, Melatonin

\section{ÖZET}

\section{Kanın Depolanmasında Görülen Oksidatif Hasarda Melatoninin Koruyucu Etkileri}

Kanın depolanması sırasında oksidatif stresin arttığı iyi bilinmekte ve depo kanın kalitesinin daha uzun sürelerle korunması için yoğun çalışmalar yapılmaktadır. Bu çalışmada, kan bankası şartlarında saklanan tam kan örneklerinde bir antioksidan olan melatoninin etkisi araştııımışıır. Sağlıkı gönüllü bir grup insandan venöz kan örnekleri, antikoagulanlı torbalara alınmıştır. Bağıştan hemen sonra kan, kontrol grubu ve melatonin grubu olarak iki gruba ayrımış ve bağış gününde ve sonraki üç hafta boyunca her hafta çeşitli biyokimyasal analizler yapılmıştır. Ortalama eritrosit ve trombosit hacim değerleri saklama boyunca artmış, ancak melatoninle bu değerler normale yakın seyretmiştir. Beklendiği gibi, saklanan kanda asidite, ozmotik frajilite ve oksidatif hasar artmıştır. Ilginç olarak, melatonin ilavesi asiditeyi, ozmotik frajiliteyi ve oksidatif hasarı (malondialdehit seviyelerini azaltıp superoksit dismutaz aktivitesini artırarak) anlamlı olarak düşürmüştür. Kontrol grubunda 14. gün pH değeri $6.68 \pm 0.04$ iken, melatonin grubunda bu değer $7.00 \pm 0.03$ idi. Malondialdehit düzeyi kontrol grubunda 21. gün $1.223 \pm 0.05$ iken melatonin grubunda bu değer $0.723 \pm 0.04$ idi $(p<0.05)$. Superoksit dismutaz aktivitesi de 14 ve 21 . günlerde melatonin grubunda (151.3 \pm 12.2 and 82.8 \pm 9.2$)$ kontrol grubuna göre anlamlı olarak yüksekti (111.8 \pm 6.5 and $44.8 \pm 3.0)(p<0.05)$. Bu sonuçlar, oksidatif hasarın tam kanın saklanmasında ortaya çıkan hasarlara neden olan mekanizmalar arasında önemli bir yer tuttuğunu ve melatoninin bu hasarlar üzerinde faydalı etkileri olduğunu göstermektedir.

Anahtar Kelimeler: Tam kan saklama, Oksidatif stress, Melatonin 


\section{INTRODUCTION}

Whole blood was the only commonly available blood product until component production systems came into general use. ${ }^{1,2}$ However, whole blood is still used in some developing countries and has been used repeatedly by the military of developed countries in Somalia, Bosnia, Kosovo and Afghanistan to replace red blood cells (RBCs) when the supply chain could not keep up with local need..$^{3-5}$ At present, the most widely used protocol for the storage of whole blood is the collection of blood into anticoagulant solutions (typically citrate-dextrose-phosphate: CDP) and storage at $4 \pm 2^{\circ} \mathrm{C}$. The studies suggest that the quality (in terms of safety and efficiency) of blood decreases during the storage period. ${ }^{6,7}$ The most dramatic changes that occur during storage include acidosis, ${ }^{8,9}$ loss of function of cation pumps and consequent loss of intracellular potassium ${ }^{10,11}$ and increased oxidative stress. ${ }^{11-13}$ An increase in oxidative stress during storage results in lipid peroxidation in which reactive oxygen species (ROS) attack the membrane and lead to loss of membrane integrity and cell death. ${ }^{14}$ To counter this potential damage, cells have antioxidant defense mechanisms of enzymatic (superoxide dismutase (SOD), catalase) ${ }^{15}$ and nonenzymatic (tocopherols, ascorbic acid) types. ${ }^{16}$ Oxidative stress occurs when there is either an overproduction of ROS or a decrease in antioxidant defenses, provoking an imbalance between antioxidant and pro-oxidant species in favor of the latter. ${ }^{16}$ This situation has been established as an underlying factor in many pathological conditions. ${ }^{17}$ Malondialdehyde (MDA) is the break-down product of the lipid peroxidation and thus serves as a reliable marker of oxidative stress. ${ }^{18,19}$ In parallel with studies on storage lesions through oxidative stress, ${ }^{20-23}$ blood preservation studies have also been conducted to understand the potential benefits arising from the addition of antioxidants into the blood. ${ }^{24-27}$ While a number of compounds have already been demonstrated to directly defend against oxidative stress in RBC membranes, ${ }^{28,29}$ melatonin as a potent antioxidant has not been used so far to defend against oxidative stress in whole blood. ${ }^{29}$ The object of the present study was therefore to investigate the effects of melatonin on several vital parameters, lipid peroxidation and anti-oxidant status in whole blood stored for up to 3 weeks.

\section{MATERIALS AND METHODS}

The procedures that follow were in accordance with the ethical standards of the local committee responsible for human experimentation and performed upon informed consent in accordance with the declaration of Helsinki. Units of whole blood were collected from healthy donor volunteers in citrate-dextrosephosphate (CDP) anticoagulant at the blood donation center of a local hospital in Ankara and stored under standard blood bank conditions. All donors met standard blood donor criteria. $300 \mathrm{ml}$ venous blood was obtained from each of 6 healthy adult male volunteers with ages ranging from 32 to 38 years of different $\mathrm{ABO}$ blood types and then stored at $4^{\circ} \mathrm{C}$ in 2 pediatric CPD-bags $(2 \times 150 \mathrm{ml})$ for each (totally 12 bags). Blood obtained from the same persons were used as both control and experiment group ( $\mathrm{n}=6$ for each group). $0.5 \mathrm{mg}$ melatonin dissolved in $2 \mathrm{ml} \mathrm{sa-}$ line was added into each of 6 different bags just after blood collection. The same amount of saline was added to control bags. $10 \mathrm{ml}$ samples were taken from bags and the number of RBC, WBC and PLTs, indexes of RBCs and platelets (MCV, MCH, MCHC, MPV, PCT), hematocrit, hemoglobin, potassium $\left(\mathrm{K}^{+}\right)$, lactate dehydrogenase (LDH), glucose, $\mathrm{pH}$, osmotic fragility, prothrombin time (PT), and activated partial thromboplastine time (aPTT) were measured on all samples initially and at 7,14 and 21 days of storage. Osmotic fragility was performed as to measure RBC resistance to hemolysis when exposed to a series of increasingly dilute saline solutions. All analyses were performed directly on the whole-blood samples and samples were removed aseptically for the analyses every week. Visual inspection of all units demonstrated no indications of bacterial contamination. The study was terminated at 21 st day because CDP is known to serve blood for 3 weeks.

For the measurement of malondialdehyde levels and superoxide dismutase activity, $4 \mathrm{ml}$ blood from each bag for each period was separated into plasma and erythrocytes by centrifugation at $1500 \mathrm{~g}$ for $10 \mathrm{~min}$, at $4^{\circ} \mathrm{C}$. The erythrocyte samples were washed three times with cold PBS and then hemolyzed by adding a fourfold volume of distilled water. Hemolyzed erythrocytes were stored at $-80^{\circ} \mathrm{C}$ for measurements, and the following parameters were studied in these hemolyzates.

Malondialdehyde (MDA) levels were measured with the thiobarbituric acid (TBA) reaction by the method 
Intermational Jounal of Hematology and $\mathrm{Oncology}_{\mathrm{y}}$

\begin{tabular}{|c|c|c|c|c|c|c|c|}
\hline & \multirow[t]{2}{*}{$\begin{array}{l}\text { INITIAL } \\
\text { LEVELS }\end{array}$} & \multicolumn{3}{|c|}{ CONTROL GROUP } & \multicolumn{3}{|c|}{ MELATONIN GROUP } \\
\hline & & Day 7 & Day 14 & Day 21 & Day 7 & Day 14 & Day 21 \\
\hline \multicolumn{8}{|c|}{ RED BLOOD CELLS \& INDEXES } \\
\hline Cell count (millions $/ \mathrm{mm}^{3}$ ) & $4.57 \pm 0.10$ & $3.75 \pm 0.35$ & $4.65 \pm 0.27$ & $4.56 \pm 0.10$ & $4.13 \pm 0.15$ & $4.78 \pm 0.29$ & $3.97 \pm 0.37$ \\
\hline Hemoglobin (g/dl) & $13.57 \pm 0.36$ & $11.37 \pm 1.08$ & $14.07 \pm 0.95$ & $13.12 \pm 0.21$ & $12.40 \pm 0.45$ & $14.55 \pm 0.97$ & $11.53 \pm 0.98$ \\
\hline Hematocrit (\%) & $39.85 \pm 1.02$ & $33.08 \pm 3.19$ & $42.53 \pm 3.16$ & $42.53 \pm 1.01$ & $36.38 \pm 1.31$ & $43.22 \pm 3.24$ & $36.40 \pm 3.23$ \\
\hline MCV (fl) & $87.20 \pm 1.07$ & $88.20 \pm 1.25$ & $91.18 \pm 1.57$ & $93.42 \pm 1.53$ & $88.13 \pm 1.05$ & $90.10 \pm 1.37^{\star}$ & $91.90 \pm 1.28^{\star}$ \\
\hline $\mathrm{MCH}(\%)$ & $29.70 \pm 0.41$ & $30.27 \pm 0.45$ & $30.18 \pm 0.39$ & $28.75 \pm 0.45$ & $30.03 \pm 0.30$ & $30.40 \pm 0.44$ & $29.18 \pm 0.45$ \\
\hline $\mathrm{MCHC}(\%)$ & $34.05 \pm 0.30$ & $34.33 \pm 0.26$ & $33.13 \pm 0.32$ & $30.88 \pm 0.33$ & $34.07 \pm 0.09$ & $33.75 \pm 0.31^{*}$ & $31.75 \pm 0.26^{\star}$ \\
\hline RDW & $12.42 \pm 0.29$ & $14.17 \pm 0.45$ & $15.10 \pm 0.68$ & $16.08 \pm 0.63$ & $13.85 \pm 0.40$ & $14.75 \pm 0.61$ & $15.12 \pm 0.48^{\star}$ \\
\hline \multicolumn{8}{|c|}{ PLATELETS \& CLOTTING FUNCTIONS } \\
\hline $\begin{array}{l}\text { Cell count } \\
\text { (thousands } / \mathrm{mm}^{3} \text { ) }\end{array}$ & $237.3 \pm 38.6$ & $266.0 \pm 27.7$ & $249.7 \pm 25.3$ & $261.8 \pm 20.7$ & $245.0 \pm 17.5$ & $238.3 \pm 24.8$ & $230.5 \pm 24.9$ \\
\hline MPV (fl) & $6.98 \pm 0.27$ & $8.20 \pm 0.40$ & $8.70 \pm 0.56$ & $8.73 \pm 0.48$ & $7.60 \pm 0.40^{*}$ & $7.27 \pm 0.23^{\star}$ & $8.05 \pm 0.43^{*}$ \\
\hline PCT & $0.16 \pm 0.02$ & $0.22 \pm 0.02$ & $0.22 \pm 0.02$ & $0.23 \pm 0.03$ & $0.19 \pm 0.01^{*}$ & $0.18 \pm 0.02^{\star}$ & $0.18 \pm 0.02^{*}$ \\
\hline PDW & $17.25 \pm 0.21$ & $16.60 \pm 0.16$ & $16.70 \pm 0.15$ & $17.93 \pm 0.35$ & $16.50 \pm 0.27$ & $17.53 \pm 0.28^{\star}$ & $17.55 \pm 0.25$ \\
\hline PT (sec) & $12.48 \pm 0.33$ & $15.87 \pm 0.23$ & $19.13 \pm 0.71$ & $20.77 \pm 0.66$ & $15.78 \pm 0.23$ & $18.25 \pm 0.40$ & $21.08 \pm 1.28$ \\
\hline INR & $0.91 \pm 0.03$ & $1.18 \pm 0.02$ & $1.49 \pm 0.07$ & $1.66 \pm 0.07$ & $1.17 \pm 0.02$ & $1.41 \pm 0.04$ & $1.70 \pm 0.13$ \\
\hline aPTा (sec) & $30.73 \pm 0.98$ & $37.17 \pm 0.51$ & $37.60 \pm 0.84$ & $39.67 \pm 1.17$ & $35.77 \pm 1.14$ & $36.17 \pm 0.80$ & $39.83 \pm 2.18$ \\
\hline \multicolumn{8}{|l|}{ WHITE BLOOD CELLS } \\
\hline $\begin{array}{l}\text { Cell count } \\
\text { (thousands/mm³) }\end{array}$ & $7.03 \pm 0.53$ & $7.68 \pm 0.49$ & $7.55 \pm 0.47$ & $7.32 \pm 0.56$ & $8.88 \pm 0.89$ & $7.35 \pm 0.61$ & $6.68 \pm 0.79$ \\
\hline
\end{tabular}

of Okhawa. ${ }^{30}$ This method was used to obtain a spectrophotometric measurement of the color produced during the reaction to TBA with MDA at $535 \mathrm{~nm}$. For this purpose, $2.5 \mathrm{ml}$ of $100 \mathrm{~g} / 1$ trichloroacetic acid solution was added to $0.5 \mathrm{ml}$ hemolysate in each centrifuge tube and placed in a boiling water bath for $15 \mathrm{~min}$. The mixture was cooled and centrifuged at $1000 \mathrm{~g}$ for $10 \mathrm{~min}$. Next, $2 \mathrm{ml}$ of the supernatant was added to $1 \mathrm{ml}$ of $6.7 \mathrm{~g} / 1 \mathrm{TBA}$ solution in a test tube, and placed in a boiling water bath for $15 \mathrm{~min}$. The solution was then cooled and its absorbance was measured with a spectrophotometer (Helios, Epsilon, USA). MDA levels were expressed as $\mathrm{nmol} / \mathrm{g}$ hemoglobin in erythrocyte hemolysates.

Superoxide dismutase (SOD) activity was assayed using the nitroblue tetrazolium (NBT) method of Sun. ${ }^{31}$ The stock solution contained $10 \mathrm{mg}$ of $\mathrm{Cu}, \mathrm{Zn}$ SOD from bovine liver dissolved in $10 \mathrm{ml}$ of isotonic saline and was diluted to 600 microgram/1 with distilled water before it was used in the assay. The SOD assay reagent consisted of a combination of the following reagents: $80 \mathrm{ml}$ of $0.3 \mathrm{mmol} / 1$ xanthine solution, $40 \mathrm{ml}$ of $0.6 \mathrm{mmol} / \mathrm{l}$ ethylenediaminetetraacetic acid (EDTA) solution, $40 \mathrm{ml}$ of $150 \mathrm{micromol} / \mathrm{l} \mathrm{NBT}$ solution, $24 \mathrm{ml}$ of $400 \mathrm{mmol} / 1 \mathrm{Na}_{2} \mathrm{CO}_{3}$ solution, and $12 \mathrm{ml}$ of bovine serum albumin. The samples were subjected to ethanol-chloroform $(62.5 / 37.5 \%)$ extraction prior to the assay of enzyme activity. Briefly, 400 microliter of ice-cold ethanol/chloroform mixture was mixed thoroughly with 250 microliter of sample. After vortexing for $30 \mathrm{~s}$ and centrifugation at $3000 \mathrm{~g}$ at $4^{\circ} \mathrm{C}$ for $5 \mathrm{~min}$, the upper aqueous layer was collected. The collected hemolysate was diluted by a factor of 100 , and $0.5 \mathrm{ml}$ of the diluted solution was used for the assay by adding to $2.5 \mathrm{ml}$ of SOD assay reagent. NBT was reduced to blue formazan by $\mathrm{O}_{2}{ }^{-}$, which has a strong absorbance at $560 \mathrm{~nm}$. One unit (U) of SOD is defined as the amount of protein that inhibits the rate of NBT reduction by $50 \%$. The calculated SOD activity was expressed as $\mathrm{U} / \mathrm{g}$ hemoglobin in erythrocyte hemolysates.

Evaluation was made by alteration curves of measured parameters and the Wilcoxon test was performed for statistical analysis. $P$ values less than 0.05 were assessed as significant. 
TABLE 2. Osmotic fragility; expressed as ratio to fragility in distilled water (Mean \pm SEM); ${ }^{*} \mathrm{p}<0.05$ when compared with control value of same day.

$\mathrm{NaCl} \quad$ Initial

concentration Level
CONTROL GROUP

\begin{tabular}{lll}
\hline Day 7 & Day 14 & Day 21 \\
$4.63 \pm 1.71$ & $11.19 \pm 3.94$ & $16.08 \pm 4.36$ \\
$9.49 \pm 2.99$ & $18.17 \pm 4.76$ & $44.54 \pm 3.34$ \\
$36.69 \pm 2.00$ & $53.33 \pm 2.81$ & $81.49 \pm 2.99$ \\
$74.73 \pm 3.49$ & $86.23 \pm 2.15$ & $99.91 \pm 3.41$ \\
$89.74 \pm 3.50$ & $95.57 \pm 1.77$ & $99.25 \pm 4.17$
\end{tabular}

MELATONIN GROUP

\begin{tabular}{lll}
\hline Day 7 & Day 14 & Day 21 \\
\hline $3.44 \pm 1.10$ & $7.63 \pm 2.47$ & $11.96 \pm 3.36$ \\
$6.47 \pm 1.95^{\star}$ & $12.08 \pm 3.58^{\star}$ & $24.22 \pm 4.76^{\star}$ \\
$24.77 \pm 2.68^{\star}$ & $38.50 \pm 2.66^{\star}$ & $61.90 \pm 2.79^{\star}$ \\
$69.80 \pm 3.25$ & $76.58 \pm 2.40$ & $99.55 \pm 1.88$ \\
$87.71 \pm 5.58$ & $86.14 \pm 4.66$ & $101.81 \pm 2.71$
\end{tabular}

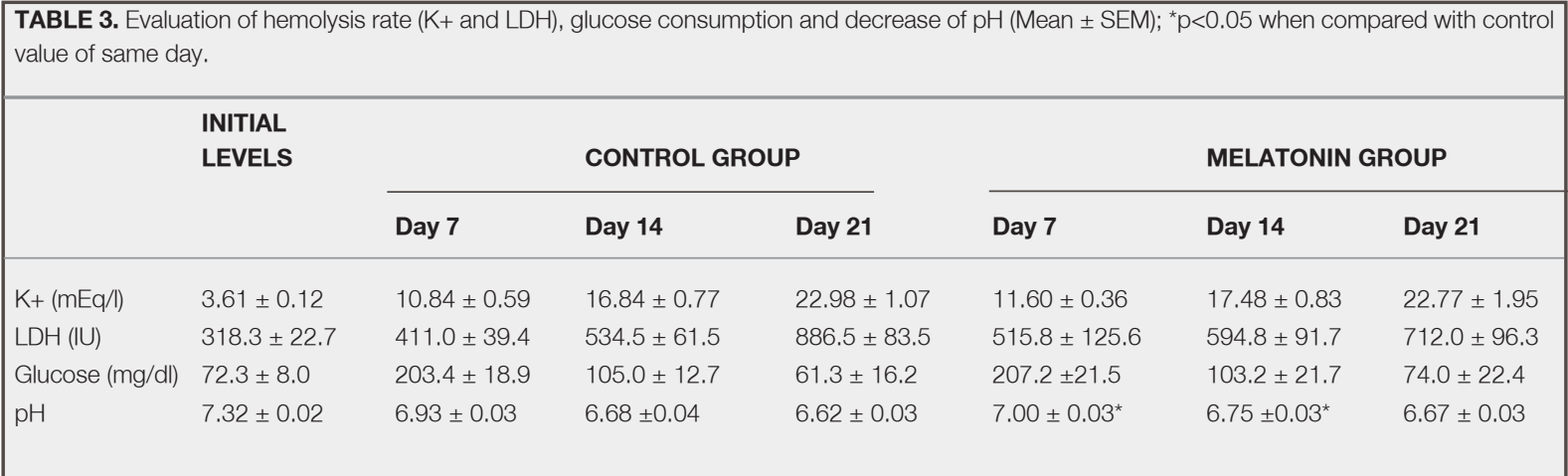

\section{RESULTS}

Red and white blood cell counts fluctuated during the storage period but did not change significantly over time and counts in melatonin group were not different compared to saline groups. However, mean corpuscular and platelet volumes (MCV and MPV) tended to increase during storing process, and with melatonin, these indices remained near to physiologic levels (Table 1). Mean corpuscular volume was $91.18 \pm 1.57$ and $93.42 \pm 1.53 \mathrm{fl}$ in days 14 and 21 of control group, while it was $90.10 \pm 1.37$ and $91.90 \pm 1.28 \mathrm{fl} \mathrm{respec-}$ tively in melatonin group $(\mathrm{p}<0.05)$. Mean platelet volume was $8.20 \pm 0.40 ; 8.70 \pm 0.56 ; 8.73 \pm 0.48 \mathrm{fl}$ in days 7, 14 and 21 of control group, while it was $7.60 \pm 0.40 ; 7.27 \pm 0.23 ; 8.05 \pm 0.43 \mathrm{fl}$ respectively in melatonin group $(\mathrm{p}<0.05)$. There was no significant difference in mean PT and aPTT between the two groups (Table 1). Osmotic fragility test showed that prolonged storage caused linear increases in hemolysis curve percentages proportionally to osmotic stress increase (at increasingly dilute $\mathrm{NaCl}$ solutions). Highest values of osmotic fragility (increase likelihood of hemolysis at lower osmotic stress) were obtained for day 21 samples, in comparison with day 0 controls, which showed the lowest osmotic fragility (Table 2).
With regard to the osmotic fragility ratios, average values of the melatonin-added group were significantly lower than that of the control bloods. Osmotic fragility ratio was $36.69 \pm 2.00 ; 53.33 \pm 2.81$ and $81.49 \pm 2.99$ in days 7,14 and 21 of control group, while it was $24.77 \pm 2.68 ; 38.50 \pm 2.66$ and $61.90 \pm$ 2.79 respectively in melatonin group $(\mathrm{p}<0.05)$.

Changes in $\mathrm{pH}$ during storage period are shown in Table 3, in which a general decrease during blood storage may be observed. Melatonin significantly prevented this decrease. $\mathrm{pH}$ was $6.68 \pm 0.04$ in day 14 of control group while it was $7.00 \pm 0.03$ in melatonin group. Similarly, the glucose concentrations decreased and potassium and LDH increased in both groups (Table 3). However melatonin presented no significant effect on these parameters.

The results obtained in the present study indicate that storage of whole blood results in higher levels of malondialdehyde but the melatonin is very effective in arresting the dramatic increase in the malondialdehyde levels (Table 4). Malondialdehyde level was $1.223 \pm 0.05$ in day 21 of control group while it was $0.723 \pm 0.04$ in melatonin group ( $\mathrm{p}<0.05$ ). Superoxide dismutase (SOD) activity during blood preser- 
Intermational Journal of Hematology and Oncology

TABLE 4. Evaluation of Oxidant (MDA) and Antioxidant (SOD) Levels (Mean \pm SEM); ${ }^{*} p<0.05$ when compared with control value of same day.

\begin{tabular}{|c|c|c|c|c|c|c|c|c|}
\hline \multirow[t]{2}{*}{ Groups } & \multicolumn{4}{|c|}{ MDA (mmol/gHb) } & \multicolumn{4}{|c|}{ SOD (U/gHb) } \\
\hline & Day 0 & Day 7 & Day 14 & Day 21 & Day 0 & Day 7 & Day 14 & Day 21 \\
\hline Control & $0.579 \pm 0.03$ & $0.618 \pm 0.03$ & $0.850 \pm 0.03$ & $1.223 \pm 0.05$ & $316.5 \pm 25.4$ & $193.7 \pm 13.3$ & $111.8 \pm 6.5$ & $44.8 \pm 3.0$ \\
\hline Melatonin & $0.538 \pm 0.02$ & $0.563 \pm 0.03$ & $0.636 \pm 0.02^{*}$ & $0.723 \pm 0.04^{*}$ & $335.0 \pm 20.2$ & $231.3 \pm 12.0$ & $151.3 \pm 12.2^{*}$ & $82.8 \pm 9.2^{*}$ \\
\hline
\end{tabular}

vation is also shown in Table 4, in which a variable decrease may be observed during three weeks in both groups, however SOD activity was significantly higher in melatonin group at days 14 and $21(151.3 \pm 12.2$ and $82.8 \pm 9.2)$ compared to saline $(111.8 \pm 6.5$ and $44.8 \pm 3.0)(\mathrm{p}<0.05)$. There was no statistically significant difference in the changes in the other parameters between groups $(\mathrm{p}>0.05)$.

\section{DISCUSSION}

In the present study, we provide supporting evidence for the relation between whole blood storage duration, and alterations in RBC metabolism and oxidative stress. It is well known that during blood preservation, blood hydrogen ion concentration and potassium levels increase. ${ }^{32-35}$ As expected, the $\mathrm{pH}$ decreased and potassium levels increased over time during storage in our study. Our findings for the $\mathrm{pH}$ and potassium are thus in agreement with previous reports. ${ }^{36-37}$ These effects of storage appear at present to be unavoidable. Potassium increase is mainly due to adenosine triphosphate (ATP) depletion, since potassium homeostasis depends on ATP-dependent maintenance of proper functioning of sodium-potassium cationic pumps. ${ }^{38}$ Storage of whole blood with melatonin for 21 days has led to marked reductions in acidity in this study while it did not affect the potassium levels. Melatonin seems to exhibit beneficial effects on $\mathrm{pH}$ in stored blood.

Results of the present study indicate that storage of whole blood for 21 days induced lipid peroxidation in RBCs. MDA is particularly released as a result of toxic effects of active oxygen radicals which destroy unsaturated fatty acids in the cell membrane.39 In RBCs, endogenous free radical scavengers seem to fail to prevent oxidative injury. Malondialdehyde levels showed a progressive increase both in control and melatonin supplemented groups, although control units showed constantly higher levels than the supplemented counterparts. In Table 4, we report that lipid peroxidation (malondialdehyde levels) was consistently lower in whole blood stored with melatonin compared to saline. On the basis of the aforementioned evidences, the observed lower levels of malondialdehyde in melatonin group may be attributed to RBC protection from oxidative stress. ${ }^{40}$ Although MDA levels were clearly decreased by melatonin, its mechanism is not clear. Melatonin may eliminate free oxygen radicals or directly increase the antioxidant enzyme activity and prevent the inhibition of these enzymes. Since antioxidant properties of melatonin are well documented, decrease in MDA levels in melatonin group is probably due its antioxidant effect. A number of drugs or chemicals have been used to prevent lipid peroxidation. 39 This is the first study in which melatonin was used for preventing lipid peroxidation injury in whole blood and it seems to be a good preservative regarding oxidant generation.

Since oxidative stress can result from increased ROS production, and/or from decreased ROS scavenging capability, SOD activity was measured. We observed a significant decrease in the activity of enzyme in control group by the 3 rd week. This may suggest that oxidative stress reduced the activity of the enzyme. As enzyme lost activity during this period, it hints that those unstable forms of enzymes that depend on fine physiological environmental requirements early become inactive. But, most of the forms do keep their functional properties until the 3 rd week, suggesting that they represent more stable enzyme forms in spite of the times passed. There are several reports indicating either decrease or increase in the antioxidant enzyme activities in oxidative injuries. ${ }^{41-44} \mathrm{~A}$ decrease in antioxidant enzyme activity was explained as being due to the interaction of enzymes with oxygen free radicals and peroxidation products which affect their active sites. ${ }^{45}$ Interestingly, SOD activity in the melatonin group is statistically higher than in the control group. An explanation for this effect of melatonin might be that it prevents the inhibition of the enzyme by toxic products, since melatonin was 
reported to preserve the activity of SOD ${ }^{46,47}$ Higher activity of SOD in melatonin supplemented blood might also be due to a reduced consumption of SOD, promoted by decreased oxidative stress levels in supplemented units (also confirmed by lower accumulation of malondialdehyde (Table 4). These results are indicative that melatonin supplementation is effective in protecting RBCs from oxidative stress. The beneficial effects of melatonin supplementation are evident at the SOD level, but also when focusing on lower accumulation of lipid oxidation product - malondialdehyde. Replenishing the RBC antioxidant battery through melatonin seems to help preserving $\mathrm{RBC}$ indices, thus confirming a central role for oxidative stress in the accumulation of the most evident RBC storage lesions.

We observed that RBCs progressively suffered from increased corpuscular volume and osmotic fragility during the storage period, as they failed to withstand higher osmotic stresses as they aged ex vivo (Table 2). These changes might be triggered both by metabolic alterations ( $\mathrm{pH}$ decrease, potassium accumulation) and, like other studies suggest, oxidative stress. ${ }^{48-51}$ The observed increase in corpuscular volume and osmotic fragility may suggest that RBC membranes had substantial alterations due to oxidative stress and lipid peroxidation (Table 4). We could confirm therefore that lipid peroxidation leads to storage membrane lesions which then increase osmotic fragility.

Whole blood drawn into plastic bags was also studied for variations of coagulation parameters. Storage of whole blood seems to have relatively little effect on the levels and function of various coagulation components. The data show that CDP-anticoagulated whole blood stored at $4^{\circ} \mathrm{C}$ for 3 weeks did not change PLT number and plasma coagulation protein activities. The observation that the PLT number and function were stable over time for the full three weeks reinforces the earlier observations that PLTs and plasma coagulation factors were not greatly damaged by cold storage..$^{52}$

A very large body of evidence indicates that melatonin is a major scavenger of oxygen-based reactive molecules. ${ }^{53-57}$ A number of studies have shown that melatonin is significantly better than the classic antioxidants in resisting free-radical-based molecular destruction. In these studies, melatonin was more effective than vitamin $E^{58-60} \beta$-carotene, ${ }^{61}$ and vitamin C. ${ }^{62,63}$ This effect is indirect, owing to its ability to scavenge free radicals and protect the protein from damage. Our study offers encouraging data supporting storage of whole blood with melatonin for at least 21 days. We conclude that whole blood seems to suffer from oxidative stress within the 21 days of storage, while the addition of melatonin is effective in arresting the dramatic oxidative changes that takes place during storage of whole blood storage. As the clinical implications for the transfusion recipient are unknown, this study should be supported with clinical investigations including different doses and a greater $\mathrm{n}$ value to get more reliable outcome.

\section{Acknowledgement}

Thanks to Ozgur Yesilyurt, M.D. and Ahmet Korkmaz, M.D. for their valuable contributions.

\section{REFERENCES}

1. Hess JR. An update on solutions for red cell storage. Vox Sang 91: 13-19, 2006.

2. Giagrande $\mathrm{P}$. The history of blood transfusion. $\mathrm{Br} \mathrm{J}$ Haematol 110: 758-767, 2000.

3. Hess JR, Thomas MJ. Blood use in war and disaster: lessons from the past century. Transfusion 43: 1622-1633, 2003.

4. Kauvar DS, Holcomb JB, Norris GC, Hess JR. Fresh whole blood transfusion: a controversial military practice. J Trauma 61: 181-184, 2006.

5. Armand R, Hess JR. Treating coagulopathy in trauma patients. Transfus Med Rev 17: 223-231, 2003.

6. Flegel WA. Fresh blood for transfusion: how old is too old for red blood cell units? Blood Transfus 10: 247-251, 2012.

7. Grazzini G, Vaglio S. Red blood cell storage lesion and adverse clinical outcomes: post hoc ergo propter hoc? Blood Transfus 10: 4-6, 2012.

8. Bennet-Guerrero E, Stafford-Smith M, Waweru PM, et al. A prospective double-blind, randomized clinical feasibility trial of controlling the storage age of red blood cells for transfusion in cardiac surgical patients. Transfusion 49: 1375-1383, 2009.

9. D'Alessandro A, Liumbruno G, Grazzini G, Zolla L. Red blood cell storage: the story so far. Blood Transfus 8: 82-88, 2010.

10. McCue JP, Vincent JM. Changes in red blood cell membrane phosphate concentration during blood bank storage. Transfusion 21: 107-112, 1981.

11. Kor DJ, Van Buskirk CM, Gajic O. Red blood cell storage lesion. Bosn J Basic Med Sci 9 (Suppl 1): 21-27, 2009.

12. Karon BS, Hoyer JD, Stubbs JR, Thomas DD. Changes in band 3 oligomeric state precede cell membrane phospholipid loss during blood bank storage of red blood cells. Transfusion 49: 1435-1442, 2009.

UHOD Number: 2 Volume: 24 Year: 2014 
13. Berezina TL, Zaets SB, Morgan C, et al. Influence of storage on red blood cell rheological properties. J Surg Res 102: 6-12, 2002.

14. Braughler JM, Hall ED. Central nervous system trauma and stroke I. Biochemical considerations of oxygen radical formation and lipid peroxidation. Free Radic Biol Med 6: 289-301, 1989.

15. Irmak MK, Fadillioglu E, Sogut S, et al. Effects of caffeic acid phenethyl ester and alpha-tocopherol on reperfusion injury in rat brain Cell Biochem Funct 21: 283-289, 2003.

16. Ozyurt H, Irmak MK, Akyol O, Sogut S. Caffeic acid phenethyl ester changes the indices of oxidative stress in serum of rats with renal ischaemia-reperfusion injury. Cell Biochem Funct 19: 259-263, 2001.

17. Frei B. Reactive oxygen species and antioxidant vitamins: Mechanism of action. Am J Med 97 (3A): S5-S13, 1994.

18. Romero FJ, Bosch-Morell F, Romero MJ, et al. Lipid peroxidation products and antioxidants in human disease. Environ Health Perspect 106: S1229-S1234, (suppl 5), 1998.

19. Diaz J, Serrano E, Acosta F, Carbonell LF. Reference intervals for four biochemistry analytes in plasma for evaluating oxidative stress and lipid peroxidation in human plasma. Clin Chem 44: 2215-2217, 1998.

20. Dumaswala UJ, Zhuo L, Jacobsen DW, et al. Protein and lipid oxidation of banked human erythrocytes: role of glutathione. Free Radic Biol Med 27: 1041-1049, 1999.

21. D'Alessandro A, D'Amici GM, Vaglio S, Zolla L. Time-course investigation of SAGM-stored erythrocyte concentrates: from metabolism to proteomics. Hematologica 97: 107-115, 2012.

22. Antonelou MH, Tzounakas VL, Velentzas AD, et al. Effects of pre-storage leukoreduction on stored red blood cells signaling: a time -course evaluation from shape to proteome. J Proteomics 76: 220-238, 2012.

23. Gevi F, D'Alessandro A, Rinalducci S, Zolla L. Alterations of red blood cell metabolome during cold liquid storage of erythrocyte concentrates in CPD-SAGM. J Proteomics 76: 10-27, 2012.

24. Dawson RB, Dabezies M, Hershey RT, et al. Blood preservation. XLIII. Studies on the ascorbate mechanisms of maintaining red cell 2,3-DPG. Transfusion 20: 316-320, 1980.

25. Dawson RB, Hershey RT, Myers CS, Eaton JW. Blood preservation XLIV. 2,3-DPG maintenance by dehydroascorbate better than D-ascorbic acid. Transfusion 20: 321-323, 1980.

26. Dawson RB, Hershey RT, Myers CS, Miller RM. Blood preservation 35. Red cell 2,3-DPG and ATP maintained by DHAascorbate-phosphate. Transfusion 21: 219-223, 1981.

27. May JM, Qu ZC, Mendiratta S. Protection and recycling of alpha-tocopherol in human erythrocytes by intracellular ascorbic acid. Arch Biochem Biophys 349: 281-289, 1998.

28. Mazor D, Golan E, Philip V, et al. Red blood cell permeability to thiol compounds following oxidative stress. Eur $\mathrm{J}$ Haematol 57: 241-246, 1996.

29. Dumaswala UJ, Wilson MJ, Wu YL, et al. Glutathione loading prevents free radical injury in red blood cells after storage. Free Radic Res 33: 517-529, 2000.
30. Okhawa H, Ohshi N, Yagi K. Assay or lipid peroxides in animal tissues by thiobarbituric acid reaction. Anal Biochem 95: 351358, 1979.

31. Sun $Y$, Oberley LW, Ying L. A simple method for clinical assay of superoxide dismutase. Clin Chem 34: 497-500, 1988.

32. Leonart MS, Nascimento AJ, Nonoyama K, et al. Enzymes and membrane proteins of ADSOL-preserved red blood cells. Sao Paulo Med J 118: 41-45, 2000.

33. Fagiolo E, Mores N, Pelliccetti A, et al. Biochemical parameters to access viability of blood storage for transfusional use. Folia Haematol 113: 783-789, 1986.

34. Noble NA, Tanaka KR, Myrhe BA, Johnson DE. Red cell enzyme activities during blood storage and reactivation of phosphofructokinase. Am J Hematol 13: 1-8, 1982.

35. Barretto OCO, Nonoyama K, Sawatani E, et al. Viablidade de sangue conservado em recipientes de várias procedências. Rev Ass Med Bras 29: 102-105, 1983.

36. Hughes JD, Macdonald WW, Hess JR. Warm storage of whole blood for 72 hours. Transfusion 47: 2050-2056, 2007.

37. Bennett-Guerrero E, Veldman TH, Doctor A, et al. Evolution of adverse changes in stored RBCs. Proc Natl Acad Sci USA. 104: 17063-17068, 2007.

38. Wallas $\mathrm{CH}$. Sodium and potassium changes in blood bank stored human erythrocytes. Transfusion 19:210-215, 1979.

39. Irmak MK, Koltuksuz U, Kutlu NO, et al. The effect of caffeic acid phenethyl ester on ischemia-reperfusion injury in comparison with alpha-tocopherol in rat kidneys. Urol Res 29: 190193. 2001.

40. Fico A, Paglialunga F, Cigliano L, et al. Glucose -6-phosphate dehydrogenase plays a crucial role in protection from redoxstress-induced apoptosis. Cell Death Differ 11: 823-831, 2004.

41. Toyoda T, Lee KS. Differential induction of superoxide dismutase in core and penumbra regions after transient focal ischemia in the rat neocortex. Neurosci Lett 10: 29-32, 1997.

42. Mishra OP, Papadopoulos MD, Wagerle LC. Anti-oxidant enzymes in the brain of newborn piglets during ischemia followed by reperfusion. Neuroscience 35: 211-215, 1990.

43. Stanimirovic DB, Micic DV, Markovic M, et al. Therapeutic window for multiple drug treatment of experimental cerebral ischemia in gerbils. Neurochem Res 19: 189-194, 1994.

44. Finkel T. Oxygen radicals and signaling. Curr Opin Cell Biol 10: 248-253, 1998.

45. Vannucci RC, Palmer C. Hypoxic-ischemic encephalopathy: pathogenesis and neuropathology. In: Neonatal-Perinatal Medicine. Fanaroff AA, Martin RJ (eds.); Mosby-Yearbook Inc: Philadelphia, 1997: 856-877.

46. Rodriguez C, Mayo JC, Sainz RM, et al. Regulation of antioxidant enzymes: a significant role for melatonin. J Pineal Res 36: 1-9, 2004.

47. Reiter RJ, Tan DX, Maldonado MD. Melatonin as an antioxidant: physiology versus pharmacology. J Pineal Res 39: 215216, 2005. 
48. Chaudhary R, Katharia R. Oxidative injury as contributory factor for red cells storage lesion during twenty eight days of storage. Blood Transfus 10: 59-62, 2012.

49. Gevi F, Zolla L. A robust high resolution reversed-phase HPLC strategy to investigate various metabolic species in different biological models. Mol Biosyst 7: 1024-1032, 2011.

50. Carrell RW, Winterbourn CC, Rachmilewitz EA. Activated oxygen and hemolysis. Br J Haematol 30: 259-264, 1975.

51. Karon BS, Van Buskirk CM, Jaben EA, et al. Temporal sequence of major biochemical events during Blood Bank storage of packed red blood cells. Blood Transfus 28: 1-9, 2012.

52. Nilsson L, Hedner U, Nilsson IM, Robertson B. Shelf-life of bank blood and stored plasma with special reference to coagulation factors. Transfusion 23: 377-381, 1983.

53. Korkmaz A, Reiter RJ, Topal T, et al. Melatonin: an established antioxidant worthy of use in clinical trials. Mol Med 15: 43-50, 2009.

54. Reiter RJ, Tan DX, Burkhardt S. Reactive oxygen and nitrogen species and cellular and organismal decline: amelioration with melatonin. Mech Ageing Dev 123: 1007-1019, 2002.

55. Reiter RJ, Tan DX, Allegra M. Melatonin: reducing molecular pathology and dysfunction due to free radicals and associated reactants. Neuro Endocrinol Lett 23 (Suppl 1): 3-8, 2002.

56. Sekeroglu MR, Huyut Z, Him A. The susceptibility of erythrocytes to oxidation during storage of blood: effects of melatonin and propofol. Clin Biochem 45: 315-319, 2012.

57. Sudnikovich EJ, Maksimchik YZ, Zabrodskaya SV, et al. Melatonin attenuates metabolic disorders due to streptozotocin-induced diabetes in rats. Eur J Pharmacol 569: 180-187, 2007.

58. Baydas G, Canatan H, Turkoglu A. Comparative analysis of the protective effects of melatonin and vitamin $\mathrm{E}$ on streptozocin-induced diabetes mellitus. J Pineal Res 32: 225-230, 2002.

59. Wahab MH, Akoul ES, Abdel-Aziz AA. Modulatory effects of melatonin and vitamin $E$ on doxorubicin-induced cardiotoxicity in Ehrlich ascites carcinoma-bearing mice. Tumori 86: 157162,2000
60. Montilla P, Cruz A, Padillo FJ, et al. Melatonin versus vitamin $E$ as protective treatment against oxidative stress after extrahepatic bile duct ligation in rats. J Pineal Res 31: 138-144, 2001.

61. Hsu C, Han B, Liu M, et al. Phosphine-induced oxidative damage in rats: attenuation by melatonin. Free Radic Biol Med 28: 636-642, 2000

62. Gultekin F, Delibas N, Yasar S, Kilinc I. In vivo changes in antioxidant systems and protective role of melatonin and a combination of vitamin $\mathrm{C}$ and vitamin $\mathrm{E}$ on oxidative damage in erythrocytes induced by chlorpyrifosethyl in rats. Arch Toxicol 75: 88-96, 2001

63. Rosales-Corral S, Tan DX, Reiter RJ, et al. Orally administered melatonin reduces oxidative stress and proinflammatory cytokines induced by amyloid-beta peptide in rat brain: a comparative, in vivo study versus vitamin $\mathrm{C}$ and $\mathrm{E}$. J Pineal Res 35: 80-84, 2003

\section{Correspondence}

Dr. IIlknur ŞENVER ÖZÇELIK

TÜBITAK MAG

Tunus Caddesi No: 80

Kavaklıdere, ANKARA / TURKEY

Tel: (+90.312) 4685300 / 1130

e-mail: ilknur.ozcelik@tubitak.gov.tr 